\title{
Corporate International Diversification and Corporate Social Responsibility: Evidence from Korean Firms
}

\author{
Chun, Hong-Min ${ }^{1}$ \\ ${ }^{1}$ School of Business, Chungbuk National University, South Korea \\ Correspondence: Chun, Hong-Min, Assistant Professor, ChungBuk National University, School of Business, \\ South Korea. Tel: 82-10-3240-6447. E-mail: hmchun@cbnu.ac.kr
}

Received: May 14, $2014 \quad$ Accepted: August 27, $2014 \quad$ Online Published: October 30, 2014
doi:10.5539/ass.v10n21p54 $\quad$ URL: http://dx.doi.org/10.5539/ass.v10n21p54

\begin{abstract}
In the process of their market globalization efforts in Korea, they have been positively utilizing corporate international diversification strategies to increase sales in overseas markets or reduce risks based on business diversification strategies. However there is mixed empirical results have been made on whether the corporate international diversification strategy made a positive or negative impact to the firm value. Extending Prior literatures, this study investigates the impacts of the level of corporate international diversification of Korean firms onto that of their corporate social responsibility activities.

Empirical result suggest that there is negative (-) association between the level of corporate international diversification and corporate social responsibility activities. In particular, this study is meaningful in demonstrating an empirical result that, even if the Korean firms pushed forward corporate international diversification strategies actively due to the stagnant domestic market in the 2000s, they actually reduced corporate social responsibility activities more greatly as they were recognized as the short-term expenses.
\end{abstract}

Keywords: corporate international diversification, corporate social responsibility

\section{Introduction}

In this study, an empirical analysis will be made to investigate the impacts of the level of corporate international diversification of Korean firms onto that of their corporate social responsibility activities. The corporate international diversification (Hereafter, CID) is a term referring to the strategies that individual firms intend to expand their business activities to the countries they belong to and the other geographical locations or markets (Cha et al., 2010). In case of some global companies such as Samsung Electronics and Hyundai Motors, they drove only a low ratio of CID strategies at domestic-oriented sales in the 1990s. On the other hand, more aggressive foreign-oriented export diversification strategies, rather than the previous domestic-oriented business strategies, were driven to report a dramatic increase in sales from the beginning of the 2000s. In this context, in order to overcome the stagnant state of growth in the domestic market, Korean firms started to be actively entering into the international markets. In the process of their market globalization efforts, they have been positively utilizing CID strategies to increase sales in overseas markets or reduce risks based on business diversification strategies. Thus, from the entry of the 2000s, the CID has been regarded as essential to Korean firms for a revenue diversification strategy, and a variety of studies have been reported to measure the economic effects of their CID endeavors.

A lot of mixed or inconsistent empirical results have been reported on whether the CID strategy made a positive or negative impact to the firm value of those individual companies, and there has been a lot of discussions in this regard (Denis et al., 2002; Gande et al., 2009; Jeong, 2003; Lee, 2003). The objectives of this study are to investigate the impacts of CID to be made onto the firm value and, furthermore, to make an empirical analysis on their impacts onto corporate social responsibility (Hereafter, CSR). According to the empirical analyses of the previous studies on the impacts of CID onto CSR activities, those companies having the high level of CID strategies participated more aggressively in CSR activities to satisfy the needs of various stakeholders, so as to demonstrate a positive $(+)$ correlation between the levels of CID and CSR (Kang 2013; Ban 2013). (Note 1) However, with regard to CSR activities, some of the following differences were found between U.S. firms and Korean ones. Even if Korean firms entered into a number of foreign countries owing to their CID strategies, they did not actively participate in the CSR-related activities which would satisfy the various stakeholders of those 
foreign nations, unlike those firms of U.S., one of the developed countries, as they were thought to be still at the early stage of the local investments in relation to their CSR activities. In other words, except for some global enterprises such as Samsung Electronics or Hyundai Motors that might take their brand image into serious consideration, the other Korean global companies that should put a priority to maximize profits through CID strategies were not likely to readily or actively participate CSR activities, because of disadvantages in costs, in spite of their aggressive CID endeavors.

In this context, a correlational direction can be predicted in advance for CID of those global enterprises. In other words, the global companies may be in unexpectedly active pursuit of CSR activities to meet the various demands of international organization or NGO (Non-Government Organization)s, along with their aggressive CID endeavors. As CSR activities have a direct impact on corporate brand image or sales growth, so that there may be a positive (+) correlation between the levels of CID and CSR activities. Meanwhile, if the global companies are obsessed with short-term profits and cost reduction despite the high level of CID, they are not likely to actively participate in CSR activities, so that it is possible to make a negative (-) correlation between the levels of CID and CSR activities. In other words, even if the global companies listed on the stock market can't help being in pursuit of maximum profits by actively carrying forward the CID strategy, they can't rule out the possibility of taking a cost minimizing strategy by intentionally reducing the CSR activities that are likely to fail a maximizing short-term performance. (Note 2) In addition, there can be mixed result between the levels of CID and CSR activities, or if no significant relationship is made between CID and CSR activities. Also there has been limited empirical studies has been done on the impacts of CID to CSR activities, so that it is considered as a challenging task of an empirical analysis that may be difficult to predict its correlational direction in advance.

An empirical analysis made with a sample of 639 companies across years, from 2005 to 2009. As a result, a negative (-) correlation was significantly demonstrated between the level of CID measured with oversea sales ratios and oversea assets ratios and that of CSR activities. As a result, a negative (-) correlation was more strongly observed in terms of consumer protection activities and employee satisfaction. In other words, it was reported that, as Korean firms were obsessed with the short-term profits, they made a reduction in CSR activities, which might be disadvantageous in terms of the short-term costs, even if the level of CID was in increase. Particularly, since any short-term investment is hard to bring a noticeable achievement in case of consumer protection activities or employee satisfaction, it was concluded that even the companies actively carrying out CID strategies were conservative or passive at the expenses for the aforementioned activities.

This study is several contributions in that it utilized Korean firms and made a direct empirical analysis to determine the impacts of existing CID strategies onto firm value or capital expenditure, and, further, onto the CSR activities which started to be emphasized more importantly in recent years. In particular, this study is also meaningful in demonstrating an empirical result that, even if the Korean firms pushed forward CID strategies actively due to the stagnant domestic market in the 2000s, they actually reduced CSR activities more greatly as they were recognized as the short-term expenses. Besides, this study makes an additional contribution by investigating the level of corporates' contribution to society while they actively carried out CID strategies. The rest of paper is organized as follows. Section 2 provides literature review regarding our main hypotheses. Section 3 presents the research design and sample selection. Section 4 contains the empirical results for our hypotheses. I conclude in Section 5.

\section{Prior Literatures and Research Hypothesis}

\subsection{Prior Literatures about Corporate International Diversification}

Korea companies have been driving CID strategies actively due to the limitations in the domestic market. As lots of mixed or inconsistent empirical results have been made on whether CID made a positive or negative effect onto the firm value. First, there were the following studies that showed a positive $(+)$ correlation between CID and firm value. Errunza and Senbet (1981) utilized oversea sales ratio as a proxy for the level of CID to look into a relationship with firm value. It was reported in the study that the companies actively carrying out their CID strategies utilized the imperfection of various capital markets differently to obtain exclusive profits, so as to successfully increase their firm value. Gande et al. (2009) reported that U.S. companies increased their firm value through the CID strategies from 1994 to 2002 while they internalized research and development costs into capitalization.

On the other hand, there were some empirical results that showed a negative (-) correlation between CID and firm value. Harris et al. (1982) reported that, as the degree of information asymmetry between headquarters and oversea divisions increased along with a higher level of CID, the entire costs related to firms' decision-making processes tended to increase, so that the firm value decreased reversely. Denis et al. (2002) also made an 
empirical analysis with a sample of 44,288 US firms across years, from 1984 to 1997, to determine the relationship between the level of CID and the firm value measured with their excess value, and reported that the companies taking CID endeavors got a discount in average on their firm value. Furthermore, Denis et al. (2002) investigated the reason of getting a discount and found that the firms having CID strategies were very likely to have made inefficient investments.

As the inconsistent empirical results reporting a mixed correlation between the level of CID of individual companies and their firm value were presented previously, an empirical analysis was made on an impact of CID onto the cost of equity capital by separating firm value. Cha et al. (2010) made an empirical analysis with a sample of 755 companies across years, from 2000 to 2005, thereby reporting that the level of CID of individual companies, measured by oversea sales and assets ratios, made a significant increase of the cost of equity capital. As described above, the impacts of CID onto the firm value was demonstrated to be inconsistent in the empirical analyses, resulting in a mixed, positive $(+)$ and/or negative (-) relationships. In addition, an empirical analysis made on the impacts of CID onto accounting or real earnings management and reported an inconsistent empirical result.

\subsection{Previous Literatures about Corporate Social Responsibility Activities}

The defenders advocating CSR activities claimed that it should be hard for companies to make a sustainable growth if they failed to mitigate interest conflicts of various stakeholders for maximization of shareholders' wealth. In particular, Guerard (1997) insisted that CSR activities make a positive influence onto corporate reputation and brand value and the active investments of individual companies generally play a positive role to their firm value. On the contrary, Ullman (1985) claimed that it should be difficult to make a direct relationship between CSR activities and business performance as no significant correlation might be found between CSR activities and business performance. Ghoul et al. (2011) made an empirical analysis on the impacts of CSR activities onto the implied cost of equity capital, reporting a negative relationship between the score of CSR activities and their implied cost of equity capital. Particularly, the companies engaging in tobacco or nuclear fuel industries, which carried out CSR activities, demonstrated a decline in their implied cost of equity capital more significantly than those engaged in the other industries. Goss and Roberts (2011) made an empirical analysis on the impacts of CSR activities of US companies onto their bank loan rates and reported an negative relationship between CSR activities and their bank loan rates. In other words, if the companies having a poor financial status carried out CSR activities, their loan rates were increased by discretionary banks that recognized the CSR activities negatively.

In contrast, some Korean studies related to CSR activities have generally reported that CSR activities played a positive role in corporate business performance and firm value (Kook \& Kang, 2011). Lee and Ko (2013) made an empirical analysis on the impacts of CSR activities of Korean firms onto their cost of equity capital. As a result of the empirical analysis, the companies carrying out superior CSR activities showed a decrease in the cost of equity capital more significantly than those which did not. In other words, investors demanded a low risk premium to those companies which actively carried out CSR activities. Thus, in summary of all the Korea and international literatures about CSR, it is possible to make a conclusion that the CSR activities have made a positive influence on the firm value and the cost of equity capital.

\subsection{Hypothesis}

As described above, there has been no consistent, positive (+) or negative (-), empirical result about the impacts of the level of CID onto their firm value or cost of equity capital. In addition, in summary of all the previous studies, CSR activities showed a positive impact onto improvement of long-term profitability and minimization of risks (Lee \& Ko, 2013; Kook \& Kang, 2011). According to Kang (2013) who made an empirical analysis on the impacts of the level of CID of U.S. firm to CSR activities, a positive (+) correlation was reported between the levels of CID and CSR activities as the firms should satisfy the needs of various stakeholders. In the case of Korean firms, the awareness of CSR activities is still in an early stage. Even the firms actively carrying out CID for revenue growth and profit maximization may recognize CSR activities as the short-term expenses, so that the possibility of reducing CSR activities can't be ruled out. In particular, domestic companies agreed with a fact that CSR activities might improve corporate profitability and reduce risks in the long-term perspective, but might be regarded as a disadvantageous factor to increase costs in the short-term perspective. Therefore, it is very likely that those companies which should control costs by actively pushing forward CID may be passive at CSR activities. Therefore, making an empirical analysis on the aforementioned subjects may be a challenging task with no specific correlational direction predictable in advance. On the basis of the aforementioned discussions, this study will make an empirical analysis on the correlation between the levels of CID and CSR activities of 
Korean firms with the following null hypothesis that has no specifically predictable direction of the positive $(+)$ or negative (-) correlation.

(Hypothesis) There is no correlation between the levels of CID and CSR activities.

\section{Research Methods}

\subsection{Measuring the Level of CID}

In this study, an empirical analysis will be made on the impacts of the level of CID of Korean firms onto that of CSR activities. The increase of CID means to face a variety of market environments having economic, geographical and cultural constraints different from the domestic market (e.g., Kang, 2013; Yoo et al., 2014). If individual firms are carrying out more aggressive foreign business activities, the revenues generated by the foreign business divisions are considered greater than domestic revenues. Similarly, if firms impose a far greater strategic weight to foreign divisions, it may be taken for granted that they are investing assets to the foreign divisions more greatly than the domestic ones. Therefore, this study also utilized oversea sales ratio and oversea assets ratios as a proxy for the level of CID, consistently with the previous studies. (Note 3)

\subsection{Measuring the Scores of CSR Activities}

In this study, The Korea economic justice index (KEJI) published by the Institute of Korea Economy belonging to the Citizens' Coalition for Economic Justice (CCEJ) was used as a proxy to measure CSR activities. KEJI was developed for comprehensive evaluation of the contribution of domestic companies to society and thus announced in 1991 for the first time when the first Economic Justice Award was given. The KEJI is made up of 7 evaluation items, 49 evaluation indicators and 4 consideration indicators. The 7 evaluation items are soundness (total score $=20$ ), fairness (total score $=11$ ), contribution to society (total score $=7$ ), consumer protection (total score $=7$ ), environmental protection satisfaction (total score $=10$ ), employee satisfaction (total score $=10$ ) and finally contribution to economic development (total score $=10$ ) out of the final total score of 75 as a whole. In summary of evaluation methods, in principle, the annual business performance of a specific year is assessed with the aforementioned evaluation items. The reasons why KEJI are used for a proxy for the social responsibility performance in this study are that the KEJI represents the most comprehensive and extensive quality assessments for ethical management and CSR and that the KEJI has ensured its reliability and stability as an evaluation method as it has been consistently used for the same purpose for more than 10 years.

\subsection{Research Model}

In order to make an empirical analysis on the impacts of the level of CID of individual firms to CSR activities, the following research model was made in this study.

$$
\begin{gathered}
\text { CSR (CSR1, CSR2, CSR3, CSR4, CSR5, CSR6) }=\beta_{0}+\beta_{1} \text { OVERSAL }(\text { OVERTA })+\beta_{2} L E V+\beta_{3} \operatorname{lnSIZE}+\beta_{4} R O A+ \\
\beta_{5} M B+\beta_{6} \text { OWNER }+\beta_{7} I O+\beta_{8} \text { TAXBURN }+ \text { Industry Dummies }+\varepsilon
\end{gathered}
$$

$C S R$ : the level of corporate social responsibility activities.

CSR1: the score of soundness and fairness.

CSR2: the score of contribution to society (community services).

CSR3: the score of consumer protection.

CSR4: the score of environmental performance (environmental protection activities).

CSR5: the score of employee satisfaction.

CSR6: the score of contribution to economic development.

OVERSAL: oversea sales.

OVERTA: oversea assets.

$L E V$ : leverage ratio.

LNSIZE: the natural log of total assets. (Note 4)

$R O A$ : return of assets.

$M B$ : market value divided by equity (market value compared to book value ratio).

OWNER: majority shareholder's ownership.

$I O$ : dummy variables indicating institutional ownership.

TAXBURN: tax burden ratio calculated by the ratio of corporate income tax to income before income taxes.

Industry Dummies: Industry-specific dummy variables classified by the medium level of Korea industry standards. (Note 5)

$\varepsilon$ : Error term.

In this study, a prediction was not made in advance about the positive (+) or negative (-) correlation between the level of CID and CSR activities. However, a positive $(+)$ sign was shown for $\beta_{1}$ if companies actively carried out 
CSR activities to meet the needs of various stakeholders along with a steady increase in the level of CID, while a negative (-) sign was shown for $\beta_{1}$ if a reduction was made in expenditure of costs in pursuit of maximization of short-term profits.

Besides, the leverage ratio, firm size and profitability were controlled as they were already determined to have a significant correlation with CSR activities in the previous studies (Kim and Chung, 2012). The direction of the relationship may be predicted easily ahead of time. If a firm has a high leverage ratio, it can be determined to have a difficulty in carrying out CSR activities actively, thereby resulting in a negative (-) correlation. On the other hand, if a firm is large in size, it can be determined to actively perform CSR activities, thereby resulting in a positive $(+)$ correlation. Lastly, a firm having high profitability can be determined to have resources to carry out CSR activities more positively, thereby resulting in a positive $(+)$ correlation. The market value divided by equity value representing the risks and growth of individual companies, the majority shareholder's ownership ratio and the dummy variables for institutional ownership ratio, the variables indicating corporate governance mechanism, were added as control variables (Mahoney and Roberts, 2007; Kang, 2013). In general, a prediction can be made on the basis of the previous studies in advance. If a firm having growth tends to carry out CSR activities more actively, a positive $(+)$ correlation can be determined between the market value divided by equity value and CSR activities. Meanwhile, the majority shareholder's ownership ratio was determined to make an unnecessary reduction in expenditure of costs, so as to result in a negative (-) correlation with corporate social expenses. The correlational direction of institutional ownership ratio was not predicted ahead of time. The measurement value of a tax burden was included as a control variable because taxation could be directly related to the resource consumption of the individual firms. Therefore, the firms having a high measurement value of a tax burden are determined to have a difficulty in actively performing CSR activities, thereby resulting in a negative (-) correlation. Lastly, as industry-specific effects of individual firms are likely to make a direct influence upon CSR activities, the industry-specific dummy variables classified by the medium level of Korea industry standards were included in the multiple regression equation to reduce effects.

\subsection{Research Sample}

In this study, some of the firms listed in Korea securities market and fulfilled the following requirements were finally pooled as a sample.

(1) Providing informational documents on their CSR activities.

(2) Providing their accounting documents taken by the KisValue (Korea Investor Service Value) of Korea Credit Rating Information Co.

(3) Their fiscal year ending at the end of December

(4) Not belonging to the financial industry sector

Requirement (4) was included as the nature of accounting subjects of the firms belonging to the financial sector is different from general firms. A sample of 639 firms, which met the aforementioned requirements, across years, from 2005 to 2009, was used for an analysis in this study.

Table 1. Distribution of number of sample across years

\begin{tabular}{lc}
\hline Year & Number of Observations \\
\hline 2005 & 113 \\
2006 & 122 \\
2007 & 123 \\
2008 & 137 \\
2009 & 144 \\
Total & 639 \\
\hline
\end{tabular}

\section{Empirical Results}

\subsection{Descriptive Statistics and Univariate Correlation Analysis}

The descriptive statistics of main variables in the empirical analysis of this study was reported in Table 2. Firstly, the mean of CSR activities (CSR), the dependent variable of this study, was 47.508. In addition, the mean of the sub-dimensions of CSR activities (CSR1-CSRO) was reported to be consistent with the empirical result of the previous study (Kim and Chung, 2012). Besides, the mean of the oversea sales ratio (OVERSAL) and oversea 
assets ratio (OVERTA), the independent variables of this study, the proxy for the level of CID, were 0.337 and 0.055 respectively. (Note 6) The mean of leverage ratio ( $L E V$ ) was reported to be 0.384 while the firm size (LNSIZE) was reported to be 27.042. The return of assets $(R O A)$ representing profitability was reported to be $5.4 \%$, and the market value divided by equity $(M B)$ was reported to be 1.219 . The majority shareholder's ownership ratio $(O W N E R)$ revealing the corporate governance level was 0.387 while the mean of the institutional ownership ratio was $34 \%$, which indicated that the institutional investors made more than $5 \%$ investments to $34 \%$ of all the companies included in this study. Lastly, the measurement value of the tax burden (TAXBURN) was $20 \%$ in average, indicating that companies carried a burden of approximately $20 \%$ in taxation.

Table 2. Distribution of main variables

\begin{tabular}{cccccc}
\hline Variables & Mean & Std. Dev. & $1 \%$ & Median & $99 \%$ \\
\hline CSR & 47.508 & 2.633 & 43.470 & 47.080 & 55.510 \\
CSR 1 & 23.469 & 2.323 & 17.790 & 23.800 & 27.720 \\
CSR2 & 4.002 & 1.096 & 1.880 & 4.020 & 6.420 \\
CSR3 & 3.349 & 0.382 & 2.250 & 3.420 & 4.200 \\
CSR 4 & 6.118 & 0.954 & 4.800 & 5.950 & 8.200 \\
CSR5 & 5.498 & 1.187 & 3.110 & 5.480 & 8.040 \\
CSR6 & 5.079 & 0.763 & 3.360 & 5.070 & 6.730 \\
OVERSAL & 0.337 & 0.296 & 0.001 & 0.254 & 0.994 \\
OVERTA & 0.055 & 0.065 & 0.000 & 0.032 & 0.328 \\
LEV & 0.384 & 0.174 & 0.084 & 0.366 & 0.833 \\
LNSIZE & 27.042 & 1.622 & 24.282 & 26.607 & 31.243 \\
ROA & 0.054 & 0.054 & -0.186 & 0.052 & 0.196 \\
MB & 1.219 & 0.974 & 0.276 & 0.906 & 5.747 \\
OWNER & 0.387 & 0.164 & 0.000 & 0.388 & 0.729 \\
IO & 0.344 & 0.476 & 0 & 0 & 1 \\
TAXBURN & 0.200 & 0.318 & -1.971 & 0.244 & 1.062 \\
\hline CSR KEN & & $C S R I$ & &
\end{tabular}

Note. CSR: KEJI Index score. CSR1: Soundness and fairness score (total score=31). CSR2: the score of contribution to society (total score=7). CSR3: the score of consumer protection (total score=7). CSR4: the score of environmental performance (total score=10). CSR5: the score of employee satisfaction (total score=10). CSR6: the score of contribution to economic development (total score=10). OVERSAL: oversea sales. OVERTA: oversea assets. $L E V$ : leverage ratio. $L N S I Z E$ : the natural $\log$ of total assets. ROA: return on assets. $M B$ : market value divided by equity. OWNER: majority shareholder's ownership. $I O$ : dummy variable which indicated that institutional ownership is over $5 \%$ then 1 , otherwise 0 . TAXBURN: tax burden ratio which is calculated by the ratio of corporate income tax to income before income taxes.

Table 3. Univariate correlations among the key variables

\begin{tabular}{cccccccccc}
\hline & $C S R$ & OVERSAL & OVERTA & LEV & LNSIZE & $R O A$ & $M B$ & OWNER & $I O$ \\
N. of Obs. & 639 & 639 & 639 & 639 & 639 & 639 & 639 & 639 & 639 \\
\hline OVERSAL & -0.027 & & & & & & & & \\
OVERTA & $\mathbf{- 0 . 1 1 3}$ & $\mathbf{0 . 6 0 5}$ & & & & & & & \\
LEV & -0.054 & $\mathbf{0 . 2 1 8}$ & $\mathbf{0 . 1 3 8}$ & & & & & & \\
LNSIZE & $\mathbf{0 . 4 0 4}$ & $\mathbf{0 . 3 3 8}$ & 0.046 & $\mathbf{0 . 4 3}$ & & & & & \\
ROA & $\mathbf{0 . 2 3 9}$ & $\mathbf{- 0 . 0 8 5}$ & 0.001 & $\mathbf{- 0 . 3 0 7}$ & 0.033 & & & & \\
MB & $\mathbf{0 . 3 4 5}$ & 0.076 & 0.068 & $\mathbf{0 . 2 3 6}$ & $\mathbf{0 . 3 5 2}$ & $\mathbf{0 . 3 3 2}$ & & & \\
OWNER & $\mathbf{- 0 . 2 8 1}$ & $\mathbf{- 0 . 0 8 1}$ & -0.05 & $\mathbf{- 0 . 1 3}$ & $\mathbf{- 0 . 2 4 1}$ & -0.067 & $\mathbf{- 0 . 3 2 3}$ & & \\
IO & $\mathbf{0 . 1 2 6}$ & 0.04 & 0.024 & 0.036 & $\mathbf{0 . 0 9}$ & $\mathbf{0 . 0 9 5}$ & $\mathbf{0 . 1 1 8}$ & $\mathbf{- 0 . 0 8}$ & \\
TAXBURN & 0.043 & -0.05 & 0.005 & -0.067 & -0.038 & $\mathbf{0 . 0 9 6}$ & 0.047 & 0.031 & 0.073 \\
\hline
\end{tabular}

Note. This table presents Pearson correlations among the key variables for the pooled sample. See note of Table 1 for the explanations of variables except for LNSIZE which is the natural log of total assets. Bold text indicates the significance at $5 \%$ level or better based on two tailed test.

Table 3 showed Pearson correlation coefficients of the main variables used in the empirical analysis of this study. Above all, CSR, the dependent variable, demonstrated a negative (-) correlation with the level of CID, but a positive $(+)$ correlation with other control variables, firm size (LNSIZE), return on assets $(R O A)$, market value 
divided by equity $(M B)$ and institutional ownership $(I O)$. On the other hand, CSR demonstrated a negative (-) correlation with the majority shareholder's ownership (OWNER). Besides, the oversea sales (OVERSAL), a substitute value indicating the level of CID, showed a positive $(+)$ correlation with the leverage ratio $(L E V)$ and firm size (LNSIZE), while it showed a negative (-) correlation with return on assets $(R O A)$ and majority shareholder's ownership (OWNER). The oversea assets ratio $(O V E R T A)$ reported a positive $(+)$ correlation with the leverage ratio $(L E V)$. Taken all the correlational analytical results into consideration, the firms having the high level of CSR demonstrated common denominators such as large firm size, high return on assets, large market value divided by equity and large institutional ownership. However, the level of CSR, the dependent variable, demonstrated a significant correlation with other variables, and, at the same time, oversea sales ratio and oversea assets ratios, the proxy for CID, also revealed a significant correlation with other variables. Thus, in order to make a more accurate analysis, it is necessary to make a further analysis based on the regression analysis, instead of simply relying on the correlational analysis. Therefore, in order to explain CID, Table 4 reported the results of the multiple regression analysis.

\subsection{Multivariate Regression Analysis}

Table 4 showed the results of the multivariate regression analysis to look into the impacts of CID to the level of CSR. This study adopted the Fama-MacBeth approach (Fama \& MacBeth, 1973) based on the annual regression analysis to remove the possibility of overestimating t-statistics which would indicate a statistical significance caused by the effects of the cross-sectional in error terms inherent to panel data. (Note 7) As a result of the regression analysis, the regression coefficient and statistical significance of the oversea sales ratio were -1.453 and -4.641 respectively, the significance level at $1 \%$, that is, showing a negative (-) correlation. In column 2 of Table 4, the oversea assets ratio was used as a proxy for the level of CID, as a result of the regression analysis, the regression coefficient and statistical significance of the oversea assets ratio were -3.316 and -2.523 respectively, the significance level at 5\%, that is, reporting a negative (-) correlation. (Note 8) Meanwhile, when the correlation among the level of CSR and other control variables was taken into consideration, the level of CSR of the firms having a large firm size and a large market value divided by equity was reported to be in increase, but that of the firms having a large leverage ratio and a large majority shareholder's ownership was reported to be in reduction. The empirical results of this study were consistent with those of the previous studies, so as to demonstrating its explanatory power of approximately $40 \%$.

Table 4. Regression between CID and CSR

\begin{tabular}{|c|c|c|c|c|c|c|}
\hline \multirow{2}{*}{$\begin{array}{c}\text { Dependent Variables } \\
\text { Variables }\end{array}$} & \multicolumn{3}{|c|}{$C S R$} & \multicolumn{3}{|c|}{ CSR } \\
\hline & coef. & & t-stat. & coef. & & t-stat. \\
\hline INTERCEPT & 25.285 & $* * *$ & 10.415 & 28.194 & $* * *$ & 14.864 \\
\hline OVERSAL & -1.453 & $* * *$ & -4.641 & & & \\
\hline OVERTA & & & & -3.316 & $* *$ & -2.523 \\
\hline$L E V$ & -4.297 & $* * *$ & -4.602 & -4.605 & $* * *$ & -8.271 \\
\hline LNSIZE & 0.883 & $* * *$ & 8.785 & 0.772 & $* * *$ & 6.744 \\
\hline$R O A$ & 2.837 & & 0.746 & 3.036 & & 1.181 \\
\hline$M B$ & 0.509 & $* * *$ & 3.949 & 0.588 & $* * *$ & 5.592 \\
\hline OWNER & -1.827 & $* * *$ & -13.911 & -1.951 & $* * *$ & -23.962 \\
\hline IO & 0.355 & & 1.035 & 0.349 & & 1.410 \\
\hline TAXBURN & -0.257 & & -0.586 & -0.296 & & -0.750 \\
\hline Industry Dummies & \multicolumn{3}{|c|}{ Included } & \multicolumn{3}{|c|}{ Included } \\
\hline Adj. $\mathrm{R}^{2}$ & \multicolumn{3}{|c|}{0.419} & \multicolumn{3}{|c|}{0.416} \\
\hline N. of Years & \multicolumn{3}{|c|}{5} & \multicolumn{3}{|c|}{5} \\
\hline N. of Obs. & \multicolumn{3}{|c|}{639} & \multicolumn{3}{|c|}{639} \\
\hline
\end{tabular}

Note. See the notes of Table 2 for the definitions of the variables. ***,** indicate, respectively, the significance level at the $1 \%$ and $5 \%$ level or better. To remove the effects of the cross-sectional correlation in error terms inherent to panel data, this study adopt the "Fama-MacBeth" approach (Fama and MacBeth 1973) to calculate the t-statistics for coefficient estimates. Industry indicators are included but not reported. 
In the previous studies about CSR, an empirical analysis was made by classifying CSR activities into sub-dimensions which might affect differently to individual firm value (Kim \& Chung, 2011). Therefore, an empirical analysis was made in the study by dividing CSR activities into six sub-dimensions, at large, such as soundness and fairness, contribution to society (community services), consumer protection, environmental performance (environmental protection activities), employee satisfaction and contribution to economic development. Table 5 showed the results of the multiple regression analysis which indicated the relationships of the levels of CID and CSR with the aforementioned sub-dimensions. According to the results of the empirical analysis, the negative correlation between the levels of CID and CSR were observed more vividly in terms of consumer protection and employee satisfaction. As described above, in terms of paying the short-term costs for the related activities, this study also reported that even the firms intending to carry out CID actively were passive or conservative to the CSR activities of fulfilling consumer protection or employee satisfaction. When the empirical results were taken into consideration, the firms actively carrying out CID tended to think little of the activities of consumer protection and employee satisfaction which would not be likely to obtain the good short-term outcome compared to investment costs.

Table 5. Regression between CID and sub-dimensions of CSR

\begin{tabular}{cccc}
\hline $\begin{array}{c}\text { Dependent } \\
\text { Variable } \\
\text { Variables }\end{array}$ & Coef & T-stat & Control Variables \\
\hline CSR1 & -0.193 & -0.66 & \\
CSR2 & -0.281 & -1.36 & \\
CSR3 & -0.151 & $-2.12^{* *}$ & Included \\
CSR4 & 0.01 & 0.07 & \\
CSR5 & -0.918 & $-4.87^{* * *}$ & \\
CSR6 & 0.128 & 1.1 & \\
\hline
\end{tabular}

Note. CSR1: Soundness and fairness score (total score $=31$ ). CSR2: the score of contribution to society (total score=7). CSR3: the score of consumer protection (total score=7). CSR4: the score of environmental performance (total score=10). CSR5: the score of employee satisfaction (total score=10). CSR6: the score of contribution to economic development (total score=10). OVERSAL: oversea sales. See the notes of Table 2 for the definitions of the variables. $* * * * *$ indicate, respectively, the significance level at the $1 \%$ and $5 \%$ level or better.

When the consistency of all the aforementioned empirical results is considered, it is possible to make a conclusion that CID is negatively associated with CSR activities. In other words, in order to overcome the stagnant domestic market, Korean firms were in an active pursuit of entering into new global markets and implementing CID strategies. However, it was also reported that they were performing the CSR activities that might reduce short-term profits in the course of the business-related efforts. Especially, as a result of the empirical analysis on the sub-dimensions of CSR activities, the study reported specifically that those firms were taking a passive attitude toward consumer protection and employee satisfaction.

\section{Conclusions}

This study suggests that the CID is negatively associated with CSR activities. In other words, as Korean firms started to enter into a variety of foreign countries, they were reported to have a tendency to focus on the short-term profits while remaining passive at the CSR investment that would need a certain level of investment costs. Then this negative association is more pronounced in consumer protection activities or employee satisfaction activities.

The empirical analysis of this study also has the following potential limitations. The oversea sales ratio and oversea assets ratio were used as the proxy for the level of CID in the study, but, if the distribution of regional and foreign business divisions is disclosed and made available, it is possible to readily make a more in-depth empirical analysis. Up to now, no specific guideline has been given to Korean firms on the degree of disclosure about their geographical business divisions. Otherwise, it is believed that there will be more in-depth follow-up studies.

Nevertheless, there is limited study has been done on this issue in Korea, this study has its own significant implications in addition to the previous studies. 


\section{Acknowledgments}

This work was supported by the research grant of the Chungbuk National University in 2013.

\section{References}

Ban, H. (2013). Corporate Social Responsibility, Earnings Quality by Corporate Diversification Strategy. Korea Business Review, 17, 27-52.

Chung, I. (2003). A Study of the Relationship between International Diversification and Organizational Performance among Korean Exporters. Korean Export Association, 28, 139-155.

Carroll, A. (1991). The Pyramid of Corporate Social Responsibility: Toward the Moral Management of Organizational Stakeholders. Business Horizons, 34, 39-48.

Cha, S., Yoo, Y., \& Chung, J. (2010). Corporate International Diversification and Cost of Equity Capital: Korean Evidence. Korean Management Research, 39, 157-175.

Denis D., \& Yost, K. (2002). Global Diversification, Industrial Diversification, and Firm Value. Journal of Finance, 5, 1951-1980. http://dx.doi.org/10.1111/0022-1082.00485

Errunza, V., \& Senbet, L. (1981). The Effect of International Operations on Market Value of the Firm: Theory and Evidence. Journal of Finance, 36, 401-417. http://dx.doi.org/10.1111/j.1540-6261.1981.tb00455.x

Gande, A., Schenzler, C., \& Senbet, W. (2009). Valuation Effect of Global Diversification. Journal of International Business Studies, 40, 1515-1532. http://dx.doi.org/10.1057/jibs.2009.59

Ghoul, S., Guedhami, O, Kwok, C., \& Mishra, D. (2011). Does Corporate Social Responsibility Affect the Cost of Capital? Journal of Banking and Finance, 35, 2388-2406.

Goss, A., \& Roberts, G. (2011). The Impact of Social Responsibility on the Cost of Bank Loans. Journal of Banking and Finance, 35, 1794-1810. http://dx.doi.org/10.1016/j.jbankfin.2010.12.002

Guerard, J. (1997). Is there a Cost to Being Socially Responsible in Investing? Journal of Forecasting, 16, 475-490.

Harris, M., Kriebel, C., \& Raviv, A. (1982). Asymmetric Information, Incentives and Intra firm Resource Allocation. Management Science, 28, 604-620. http://dx.doi.org/10.1287/mnsc.28.6.604

Hughes, L., Logue, D., \& Sweeny, R. (1975). Corporate International Diversification and Market Assigned Measure of Risk and Diversification. Journal of Financial Risk and Diversification, 10, 627-637.

Jo, J., Park, J., \& Cho, M. (2008). A Study on the Segment Reporting of Korean Firms. Korean Accounting Journal, 17, 191-223.

Kang, J. (2013). The Relationship between Corporate Diversification and Corporate Social Performance. Strategic Management Journal, 34, 94-109. http://dx.doi.org/10.1002/smj.2005

Kemsley D., Nissim, D., \& Williams, M. (2002). Taxes and the Information Content of Dividends. Working paper. Columbia University.

Kim, S., \& Chung, Y. (2012). Monitoring Power of Foreign Ownership on Corporate Social Responsibility: Evidence from Korea. Korean Accounting Review, 37, 1-62.

Kook, C., \& Kang, Y. (2011). Corporate Social Responsibility, Corporate Governance and Firm Value. The Journal of Korean Securities Association, 40, 713-748.

Lee, J. (2003). International Diversification, Product Diversification, Organizational Learning, their Interactions and Firm Value. Korean Management Research, 32, 1291-1315.

Lee, Y., \& Ko, J. (2013). The Effect of Corporate Social Responsibility on the Cost of Equity Capital and Information Asymmetry. Korean Accounting Journal, 22, 159-193.

Mahoney, L., \& Roberts, R. (2007). Corporate Social Performance and Institutional Ownership in Canadian Firms. Accounting Forum, 34, 233-253. http://dx.doi.org/10.1016/j.accfor.2007.05.001

Pava. M., \& Krausz, J. (1996). The Association between Corporate Social Responsibility and Financial Performance: The Paradox of Coxial Cost. Journal of Business Ethics, 15, 321-357.

Ullman, A. (1985). Data in Search of a Theory: A Critical Examination of the Relationships among Social Performance, Social Disclosure and Economic Performance of US Firms. The Academy of Management Review, 10, 540-557. http://dx.doi.org/10.5465/AMR.1985.4278989 
Yoo, Y., Kim, H., \& Chun, H. (2014). Corporate International Diversification and Real Earnings Management. Korean Accounting Review, 39, 293-322.

\section{Notes}

Note 1. Ban (2013) made an empirical analysis with a sample of some specific Korean firms on the impacts of CID onto CSR from 2008 to 2010, resulting in a report that CID made a positive correlation, that is, an increase proportional to corporate social expenditure to meet the needs of various stakeholders. Ban (2013) made an empirical analysis by utilizing only the oversea sales ratio as a measurement value of the level of CID for the period of years, 2008 through 2010. Meanwhile this study made an empirical analysis by utilizing oversea sales and assets ratios as aproxy for the level of CID from 2005 to 2009. This study reported a significant negative (-) relationship between CID and CSR in its correlation analysis and Fama-Macbath (1973) and Pooled OLS regression analysis.

Note 2. The previous studies found the reason why firms were reluctant about CSR activities that the firms pursuing the maximization of shareholders' wealth should take a risk of a certain level of costs required for CSR activities as it might bring a negative impact onto firm value. In particular, according to the Eastern Asia Research Institute, an investment effect was reported to be very small even if 202 and 222 Korean firms spent 1.087 trillion won in 2002 and 3.124 trillion won in 2011, respectively, on CSR activities, specifically, contribution to society. It is because that people believe that those firms put a greater emphasis of their CSR activities on the improvement of their corporate image than on active contribution to society.

Note 3. According to Jo et al. (2008) who investigated the information on disclosure status of business-wise divisions of manufacturers listed in the securities market in 2006, only 184 firms out of the total of $456,40.3 \%$, provided the information on their business- or region- divisions in their business report at the electronic disclosure system led by Financial Supervisory Service. Specifically, 167 firms out of 184 disclosed the information only on their business-wise divisions, only 4 on their region-wise divisions and 13 on both of their business- and region- divisions. In conclusion, Korean firms generally make a business-wise, rather than region-wise disclosure, and, thus, almost no Korean firm makes a disclosure on foreign divisions restrictively.

Note 4. In order to control a bias in the distribution of total assets, the natural log of the same variable (LNSIZE) was used as a substitute value in the following empirical analysis.

Note 5. In the empirical analysis of the study, the so-called Fama-MacBeth (Fama and MacBeth 1973) approach based on the annual regression analysis was in use, so that it was not necessary to additionally control the annual dummy variables.

Note 6. In order to minimize the effect of extreme values in the study, the values, smaller (larger) than 1 (99)\% of the total distribution, were replaced with $1(99) \%$ of the relevant distributions.

Note 7. The method developed by Kemsley and Nissim (2002) was used for the t-value which would indicate a statistical significance of the relevant regression coefficient, so that it was the t-value calculated by adjusting the primary self-correlation of those annual regression coefficients.

Note 8. As a result of the Pooled OLS regression empirical analysis, the regression coefficient and statistical significance of the oversea sales ratio were -1.398 and -3.35 respectively, the significance level at $1 \%$, that is, showing a negative (-) correlation.

\section{Copyrights}

Copyright for this article is retained by the author(s), with first publication rights granted to the journal.

This is an open-access article distributed under the terms and conditions of the Creative Commons Attribution license (http://creativecommons.org/licenses/by/3.0/). 